Article

\title{
Equimolar Yttria-Stabilized Zirconia and Samaria-Doped Ceria Solid Solutions
}

\author{
Reginaldo Muccillo ${ }^{1,2, *}$, Daniel Z. de Florio ${ }^{2}\left(\mathbb{C}\right.$ and Eliana N. S. Muccillo ${ }^{1[(]}$ \\ 1 Energy and Nuclear Research Institute, São Paulo 05508-900, Brazil; enavarro@usp.br \\ 2 Center of Engineering, Modeling and Applied Social Sciences, Federal University of ABC, \\ Santo André 09210-580, Brazil; daniel.florio@ufabc.edu.br \\ * Correspondence: muccillo@usp.br; Tel.: +55-11-997-001-943
}

Received: 18 October 2018; Accepted: 20 November 2018; Published: 22 November 2018

\begin{abstract}
Compositions of $\left(\mathrm{ZrO}_{2}\right)_{0.92}\left(\mathrm{Y}_{2} \mathrm{O}_{3}\right)_{0.08}$ (zirconia: $8 \mathrm{~mol} \%$ yttria- $8 \mathrm{YSZ}$ ) and $\left(\mathrm{CeO}_{2}\right)_{0.8}\left(\mathrm{Sm}_{2} \mathrm{O}_{3}\right)_{0.2}$ (ceria: $20 \mathrm{~mol} \%$ samaria-SDC20) ceramic powders were prepared by attrition milling to form an equimolar powder mixture, followed by uniaxial and isostatic pressing. The pellets were quenched to room temperature from $1200{ }^{\circ} \mathrm{C}, 1300{ }^{\circ} \mathrm{C}, 1400{ }^{\circ} \mathrm{C}$ and $1500{ }^{\circ} \mathrm{C}$ to freeze the defects configuration attained at those temperatures. X-ray diffraction analyses, performed in all quenched pellets, show the evolution of the two (8YSZ and SDC20) cubic fluorite structural phases to a single phase at $1500{ }^{\circ} \mathrm{C}$, identified by Rietveld analysis as a tetragonal phase. Impedance spectroscopy analyses were carried out in pellets either quenched or slowly cooled from $1500^{\circ} \mathrm{C}$. Heating the quenched pellets to $1000{ }^{\circ} \mathrm{C}$ decreases the electrical resistivity while it increases in the slowly cooled pellets; the decrease is ascribed to annealing of defects created by lattice micro-tensions during quenching while the increase to partial destabilization of the tetragonal phase.
\end{abstract}

Keywords: solid electrolytes; yttria-stabilized zirconia; samaria-doped ceria; X-ray diffraction; impedance spectroscopy

\section{Introduction}

Similar to what happens to high-entropy alloys [1-4], high-entropy oxides or entropy-stabilized oxides are compounds that result from the combination of an equimolar content of several oxides prepared in such a way that the cations are randomly distributed in the cationic sublattice [5]. The preparation involves heat treatment at temperatures that allow for the migration of the cations to thermodynamically minimum energy sites, followed by quenching to room temperature to retain the thermodynamic configuration achieved at high temperatures. X-ray diffraction is the main technique to monitor the phase constitution of the primary components and the evolution of the crystalline structure to that of the final compound. If that transition is reversible, i.e., if the compound can be decomposed back to the primary components, the transition is recognized as entropy-driven [5]. The thermodynamically metastable new compound may have new structural phases and/or lattice parameters with new, eventually enhanced, physical properties. A series of experiments was reported on a new compound based on an equimolar mixture of $\mathrm{MgO}, \mathrm{CoO}, \mathrm{NiO}, \mathrm{CuO}$ and $\mathrm{ZnO}$, a five-component oxide with high configurational entropy [5].

Aliovalent substitutions of cations in high-entropy oxides lead to a large number of possible combinations allowing for the synthesis of many new compounds. This opens an opportunity for discovering new compounds with improved properties, like colossal dielectric constants [6]. Preliminary results on lithium and sodium fast ion conductors were reported on $(\mathrm{MgCoNiCuZn})_{1-x-y} \mathrm{Ga}_{y}(\mathrm{Li} \text { or } \mathrm{Na})_{\mathrm{x}} \mathrm{O}$ [7]. Some recent publications deal with synthesis, phase stability and properties of high-entropy oxides: with fluorite structure $\left(\mathrm{HfO}_{2}, \mathrm{ZrO}_{2}\right.$ and $\left.\mathrm{CeO}_{2}\right)$ with 
additions of $\mathrm{Y}, \mathrm{Yb}, \mathrm{Ca}, \mathrm{Ti}, \mathrm{La}, \mathrm{Mg}$, and $\mathrm{Gd}$ oxides as fluorite phase stabilisers [8]; multicomponent rare earth oxides [9]; high entropy single-phase oxide with even 10 components ( $\mathrm{Gd}, \mathrm{La}, \mathrm{Nd}, \mathrm{Sm}, \mathrm{Y}, \mathrm{Co}, \mathrm{Cr}$, $\mathrm{Fe}, \mathrm{Mn}$ and $\mathrm{Ni}$ ), with a multiphase-single phase reversibility under heating [10]; $(\mathrm{Co}, \mathrm{Cr}, \mathrm{Fe}, \mathrm{Mn}, \mathrm{Ni})_{3} \mathrm{O}_{4}$ high entropy oxide with spinel structure [11], high-entropy multicomponent perovskite solid solutions $\mathrm{Sr}_{1-\mathrm{x}} \mathrm{Ba}_{\mathrm{x}}\left(\mathrm{Zr}_{0.2} \mathrm{Sn}_{0.2} \mathrm{Ti}_{0.2} \mathrm{Hf}_{0.2} \mathrm{~A}_{0.2}\right) \mathrm{O}_{3}(\mathrm{x}=0.5, \mathrm{~A}=\mathrm{Mn}, \mathrm{Nb}, \mathrm{Ce}, \mathrm{Y})$ [12].

It has been suggested that entropy-stabilisation is a "particularly effective compound with ionic character", we investigated this suggestion using equimolar combinations of paradigmatic ionic conductors $\mathrm{ZrO}_{2}: 8 \mathrm{~mol} \% \mathrm{Y}_{2} \mathrm{O}_{3}$ (8YSZ) and $\mathrm{CeO}_{2}: 20 \mathrm{~mol} \% \mathrm{Sm}_{2} \mathrm{O}_{3}$ (SDC20). 8YSZ is already commercially available, as a component of electrochemical devices allowing for the environmentally compatible production of electrical energy, heat, and high-temperature solid oxide fuel cells $\left(800-1000{ }^{\circ} \mathrm{C}\right.$ HT-SOFCs) [13-17]. SDC20 was proposed as a candidate to substitute 8YSZ in these devices to enable a decrease in operating temperature to intermediate temperatures $\left(600-800{ }^{\circ} \mathrm{C}\right.$ IT-SOFCs) [18-21].

Chemical species are known to be accumulated or depleted at the interfaces of ceramic ionic conductors, creating a space charge region, which is considered to be responsible for the blocking of oxide ions, inhibiting their transport across the grain boundaries. This leads to the grain boundary resistivity detected as a low-frequency semicircle in the impedance diagrams in oxides conventionally sintered [22-29].

The purpose of this paper was to look at the distribution of charged species at the interface of solid solutions of equimolar $\mathrm{ZrO}_{2}: 8 \mathrm{~mol} \% \mathrm{Y}_{2} \mathrm{O}_{3}$ and $\mathrm{CeO}_{2}: 20 \mathrm{~mol} \% \mathrm{Sm}_{2} \mathrm{O}_{3}$, either quenched or slowly cooled from high temperatures, by collecting impedance spectroscopy data.

\section{Materials and Methods}

The ceramic powders were commercial $\mathrm{ZrO}_{2}: 8 \mathrm{~mol} \% \mathrm{Y}_{2} \mathrm{O}_{3}$ (8YSZ, Tosoh, Tokyo, Japan) with $16 \pm 3 \mathrm{~m}^{2} / \mathrm{g}$ surface area, and $\mathrm{CeO}_{2}: 20 \mathrm{~mol} \% \mathrm{Sm}_{2} \mathrm{O}_{3}$ (SDC20, Fuel Cell Materials, Lewis Center, $\mathrm{OH}$, USA) with $36.1 \mathrm{~m}^{2} / \mathrm{g}$ surface area. $10 \mathrm{~g}$ of equimolar amounts of both powders were thoroughly mixed in an agate mortar. Afterwards the mixed powders were attrition milled at $5000 \times \mathrm{rpm}$ with sintered ceramic spheres of $1 \mathrm{~mm}$ diameter tetragonal zirconia $\left(\mathrm{ZrO}_{2}: 5 \mathrm{~mol} \% \mathrm{Y}_{2} \mathrm{O}_{3}\right.$, Tosoh, Tokyo, Japan) and isopropyl alcohol in a custom-made polytetrafluoroethylene (Teflon $\left.{ }^{\circledR}\right)$-lined metallic jar; this procedure was repeated four times for $15 \mathrm{~min}$ milling, with intermediate resting to avoid excessive heating that could result in powder agglomeration. The powders were uniaxially pressed into cylindrical shape pellets ( $\varphi 5 \mathrm{~mm} \times 3 \mathrm{~mm}$ ) at $10 \mathrm{MPa}$ and isostatically (National Forge Co., Irvine, CA, USA) at $200 \mathrm{MPa}$. The geometrical density of all samples was $40-45 \%$ TD (TD: theoretical density). The sequence to quench the oxides was to insert the samples (two similar at a time) inside a programmable furnace (Lindberg Blue M, Watertown, WI, USA) previously heated at 1200, 1300, 1400 and $1500^{\circ} \mathrm{C}$ using a Pt mesh and Pt wires to pull the samples in and out the furnace at $100^{\circ} \mathrm{C} / \mathrm{s}$ heating rate and $100{ }^{\circ} \mathrm{C} / \mathrm{s}$ cooling rate to room temperature. Similar samples were heated to $1500{ }^{\circ} \mathrm{C}$ at $0.17^{\circ} \mathrm{C} / \mathrm{s}$ and cooled at the same rate to room temperature.

X-ray diffraction analyses were carried out at room temperature with a Bruker-AXS D8 Advance diffractometer (Karlsruhe, Germany), Bragg-Brentano configuration, with $\mathrm{Cu} \mathrm{k}_{\alpha}$ radiation $(\lambda=1.54049 \AA)$ in the $20-802 \theta$ range, $0.02^{\circ}$ step size, 10 s step time. The patterns had their background subtracted with the EVA ${ }^{\circledR}$ Bruker-AXS software. Rietveld refinement analyses of the diffraction patterns were performed with the Topas ${ }^{\circledR}$ software with five diffraction lines for $\mathrm{Cu} \mathrm{k}_{\alpha}$ radiation. The crystal structure information was collected in the Inorganic Crystal Structure Database (ICSD). The background was evaluated with a fifth order Chebyshev polynomial; Lorentz polarization was fixed at zero; lattice parameters, scale factor, Lorentz and/or Gauss contribution to crystal size, and sample displacement were allowed to be refined simultaneously.

Impedance spectroscopy measurements were carried out with a Hewlett Packard 4192A impedance analyzer (Yokogawa-Hewlett Packard, Tokyo, Japan) with $200 \mathrm{mV}$ input signal, 20 points per decade in the $5-13 \mathrm{MHz}$ frequency range, in samples spring-loaded between platinum disks inside a sample chamber made of inconel 600, alumina, and platinum terminal leads. Silver paste was deposited on the parallel surfaces of the ceramic green pellets and cured at $300{ }^{\circ} \mathrm{C} / 15 \mathrm{~min}$. For the 
collection of the impedance data, a model 360 Hewlett Packard Controller was used; the collection, analysis and deconvolution of the $\left[-Z^{\prime \prime}(f) \times Z^{\prime}(f)\right]$ impedance diagrams were performed with a special software [30]; $Z^{\prime}$ and $Z^{\prime \prime}$ are the real and the imaginary components of the impedance and $f$ is the frequency of the input signal. Specimens with similar diameter and thickness were used, being needless to correct data by considering their geometric factors.

The surfaces of the sintered specimens were polished with diamond pastes (15 $\mu \mathrm{m}$ to $1 \mu \mathrm{m})$ and thermally etched for $15 \mathrm{~min}$ at a temperature 100 degrees lower than the sintering temperature for observation in a scanning electron microscope (Inspect F50 FEG-SEM, FEI, Brno, Czech Republic).

\section{Results}

\subsection{X-ray Diffraction Analysis}

Figure 1 shows the results of the $X$-ray diffraction analysis of equimolar $\mathrm{ZrO}_{2}: 8 \mathrm{~mol} \% \mathrm{Y}_{2} \mathrm{O}_{3}+$ $\mathrm{CeO}_{2}: 20 \mathrm{~mol} \% \mathrm{Sm}_{2} \mathrm{O}_{3}$ green pellets heated to and quenched from 1200, 1300, 1400 and $1500{ }^{\circ} \mathrm{C}$.

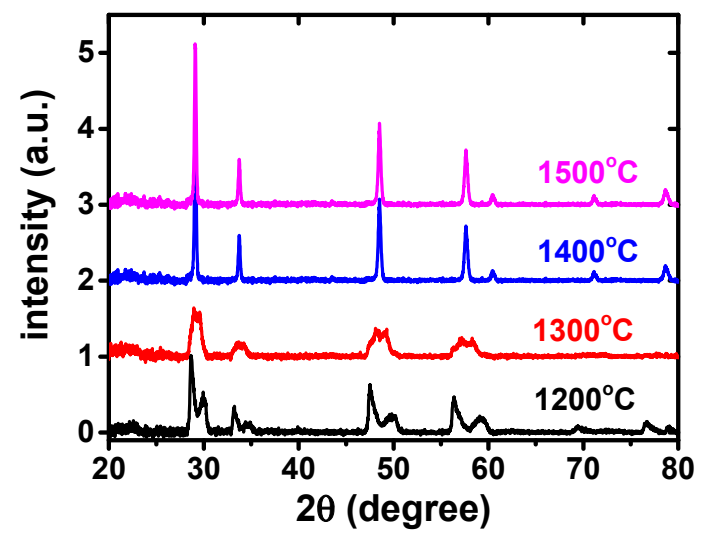

Figure 1. X-ray diffraction patterns showing the phase evolution of equimolar $\mathrm{ZrO}_{2}: 8 \mathrm{~mol} \% \mathrm{Y}_{2} \mathrm{O}_{3}+$ $\mathrm{CeO}_{2}: 20 \mathrm{~mol} \% \mathrm{Sm}_{2} \mathrm{O}_{3}$ ceramic pellets quenched from 1200, 1300, 1400 and $1500{ }^{\circ} \mathrm{C}$.

It was apparent that a single phase was reached at $1500{ }^{\circ} \mathrm{C}$. The next step was to prepare $\mathrm{ZrO}_{2}$ : $8 \mathrm{~mol} \% \mathrm{Y}_{2} \mathrm{O}_{3}+\mathrm{CeO}_{2}: 20 \mathrm{~mol} \% \mathrm{Sm}_{2} \mathrm{O}_{3}$ pellets quenched from $1500{ }^{\circ} \mathrm{C}$ to compare with each of the component compositions quenched from $1500{ }^{\circ} \mathrm{C}$ as well. The X-ray diffraction patterns of 8YSZ, SDC20 and the equimolar 8YSZ + SDC20 mixture are shown in Figure 2. 


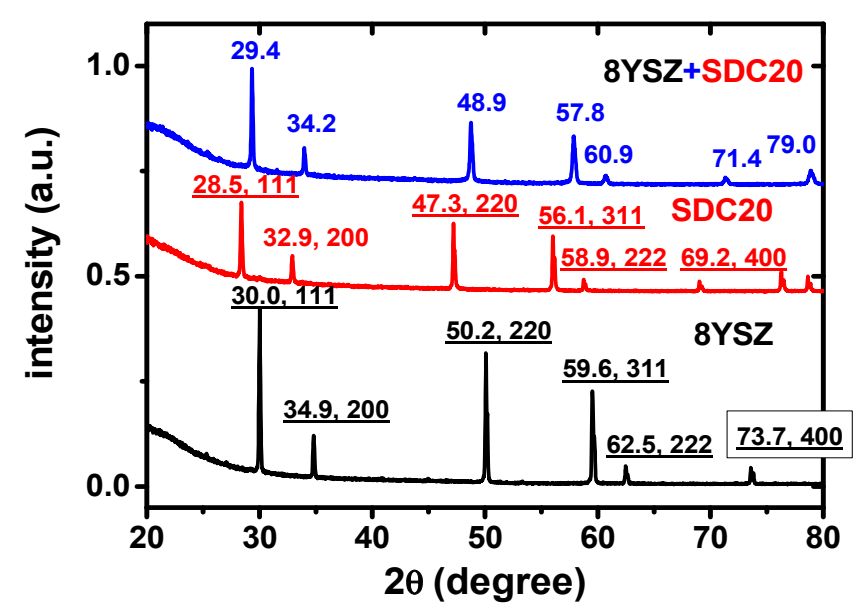

Figure 2. X-ray diffraction patterns, from bottom to top, of $\mathrm{ZrO}_{2}: 8 \mathrm{~mol} \% \mathrm{Y}_{2} \mathrm{O}_{3}$ (8YSZ), $\mathrm{CeO}_{2}: 20 \mathrm{~mol}$ $\% \mathrm{Sm}_{2} \mathrm{O}_{3}$ (SDC20), and equimolar $8 \mathrm{YSZ}+\mathrm{SDC} 20$ ceramic pellets quenched from $1500{ }^{\circ} \mathrm{C}$. Numbers refer to $2 \theta$ peak diffraction angles (top) and peak diffraction angles with known Miller indices (middle and bottom).

The typical X-ray diffraction peaks of 8YSZ and SDC20 are not present in the diffraction pattern of the quenched equimolar mixture, indicating that a new structural phase is formed, with the peak $2 \theta$ X-ray diffraction angles lying between the 8YSZ and SDC20. For example, the largest amplitude 111 reflections of SDC20 and 8 YSZ have a peak maximum at $28.5^{\circ}$ and $30.0^{\circ}$, respectively, while the corresponding quenched equimolar mixture peaks at $29.4^{\circ}$. The results of the Rietveld analysis are shown in Figure 3. The solid solution of the two cubic fluorite phases belonging to yttria-stabilized zirconia and samaria-doped ceria has a new crystallographic structure, a single tetragonal phase. Moreover, the Bragg peaks are narrow, and no other peaks are detected.

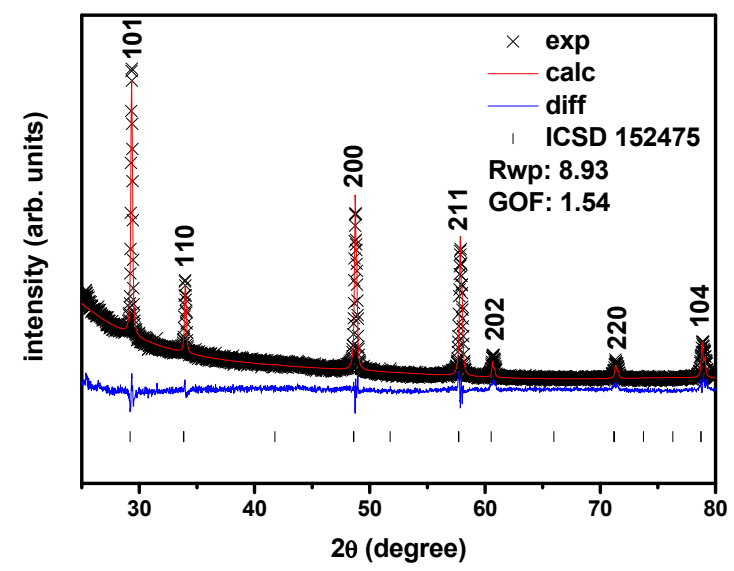

Figure 3. X-ray diffraction patterns of equimolar $\mathrm{ZrO}_{2}: 8 \mathrm{~mol} \% \mathrm{Y}_{2} \mathrm{O}_{3}+\mathrm{CeO}_{2}: 20 \mathrm{~mol} \% \mathrm{Sm}_{2} \mathrm{O}_{3}$ ceramic pellets quenched from $1500{ }^{\circ} \mathrm{C}$ and the calculated lines corresponding to the best fitted structure after the Rietveld analysis.

\subsection{Scanning Electron Microscopy}

Figure 4 shows scanning electron microscopy images of the surfaces of the 8YSZ, SDC20 and equimolar $8 \mathrm{YSZ}+\mathrm{SDC} 20$ mixture, quenched from $1500^{\circ} \mathrm{C}$, polished and thermally etched at $1400{ }^{\circ} \mathrm{C}$. 


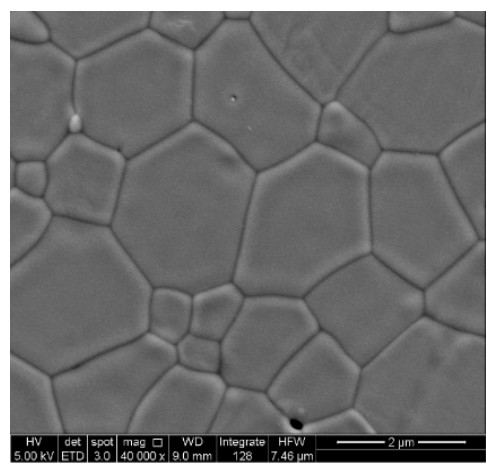

8YSZ $\left(\mathrm{ZrO}_{2}: 8 \mathrm{~mol} \% \mathrm{Y}_{2} \mathrm{O}_{3}\right)$

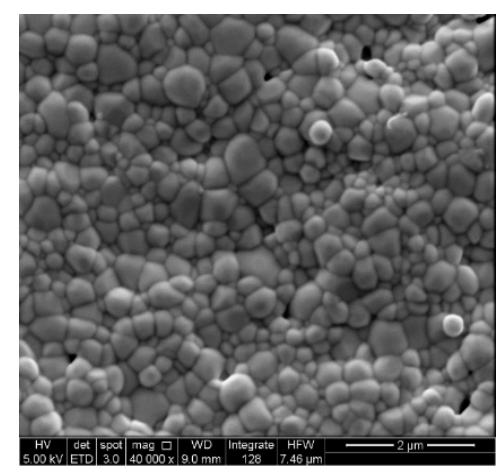

$\operatorname{SDC} 20\left(\mathrm{CeO}_{2:} 20 \mathrm{~mol}_{\%} \mathrm{Sm}_{2} \mathrm{O}_{3}\right)$

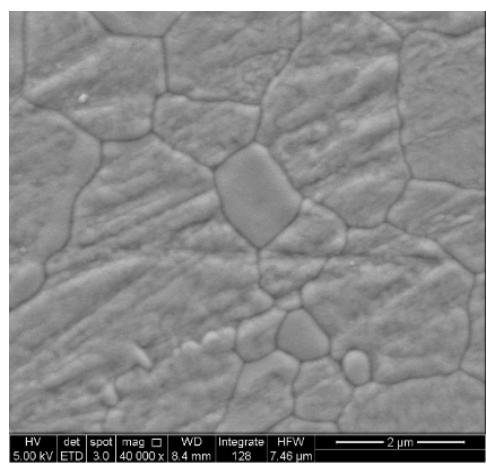

equimolar $8 \mathrm{YSZ}+\mathrm{SDC} 20$

Figure 4. Scanning electron microscopy micrographs of polished and thermally etched surfaces of $\mathrm{ZrO}_{2}: 8 \mathrm{~mol} \% \mathrm{Y}_{2} \mathrm{O}_{3}$ (8YSZ), $\mathrm{CeO}_{2}: 20 \mathrm{~mol} \% \mathrm{Sm}_{2} \mathrm{O}_{3}$ (SDC20) and equimolar 8YSZ + SDC20 mixture, all quenched from $1500{ }^{\circ} \mathrm{C}$.

\subsection{Impedance Spectroscopy Analysis}

Impedance spectroscopy measurements were carried out in the three cold-pressed pellets quenched from $1500{ }^{\circ} \mathrm{C}$ to room temperature: 8YSZ, SDC20 and their equimolar mixture. The results are shown in Figure 5.

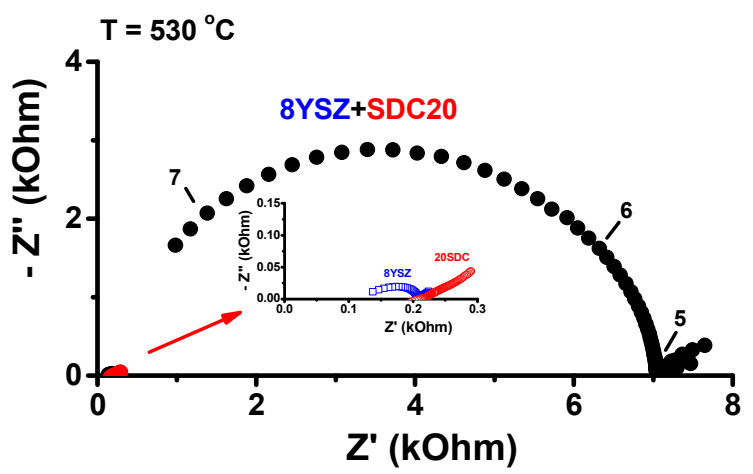

Figure 5. Impedance spectroscopy diagrams, of $\mathrm{ZrO}_{2}: 8 \mathrm{~mol} \% \mathrm{Y}_{2} \mathrm{O}_{3}, \mathrm{CeO}_{2}: 20 \mathrm{~mol} \% \mathrm{Sm}_{2} \mathrm{O}_{3}$ and equimolar $\mathrm{ZrO}_{2}: 8 \mathrm{~mol} \% \mathrm{Y}_{2} \mathrm{O}_{3}+\mathrm{CeO}_{2}: 20 \mathrm{~mol} \% \mathrm{Sm}_{2} \mathrm{O}_{3}$ ceramic pellets quenched from $1500{ }^{\circ} \mathrm{C}$. Numbers stand for $\log \mathrm{f}\left(\mathrm{f}: \mathrm{Hz}\right.$ ). Temperature of measurement: $530^{\circ} \mathrm{C}$. Inset: Enlarged view of the low resistance region with the 8YSZ and SDC20 impedance diagrams.

The impedance diagrams measured at $530{ }^{\circ} \mathrm{C}$ show an interesting behavior: the frequency response of the impedance of the quenched equimolar sample presents only one semicircle in the $10^{5}-10^{7} \mathrm{~Hz}$ frequency range, typical of a $\mathrm{R} / \mathrm{C}$ component corresponding to the bulk contribution to the electrical resistivity, with $\mathrm{R}=7.0 \mathrm{kOhm}$ and $\mathrm{C}=1.0 \times 10^{-12} \mathrm{~F}$ [31]. Even though the electrical resistance is $\sim 35$ times higher than those of 8 YSZ and SDC20 $(\sim 0.22$ and $\sim 0.21 \mathrm{kOhm}$, respectively $)$, apparently there is no contribution from the interfaces, namely, grain boundaries. To check the possibility of annealing out the defects produced by stress in the bulk of the sample during the quenching process, impedance spectroscopy measurements were carried out in a sample quenched from $1500{ }^{\circ} \mathrm{C}$ with further heat treatments at $1000{ }^{\circ} \mathrm{C}$. The pellets of the equimolar mixture quenched from $1500{ }^{\circ} \mathrm{C}$ were then heated to $1000{ }^{\circ} \mathrm{C}$ for different dwelling times ( 1 and $30 \mathrm{~min}$ ) to relieve possible tensions caused by the quenching process. The impedance and the Bode diagrams of the quenched sample before and after $1000{ }^{\circ} \mathrm{C}$ annealing are shown in Figure 6. A decrease of the total electric resistance from $7.0 \mathrm{kOhm}$ to $5.5 \mathrm{kOhm}$ is measured; both diagrams have a similar shape, with only one semicircle due to the 
bulk resistivity. The Bode diagrams of the imaginary component of the impedance are also plotted to ascertain that there is only one response corresponding to one semicircle in the impedance diagram.
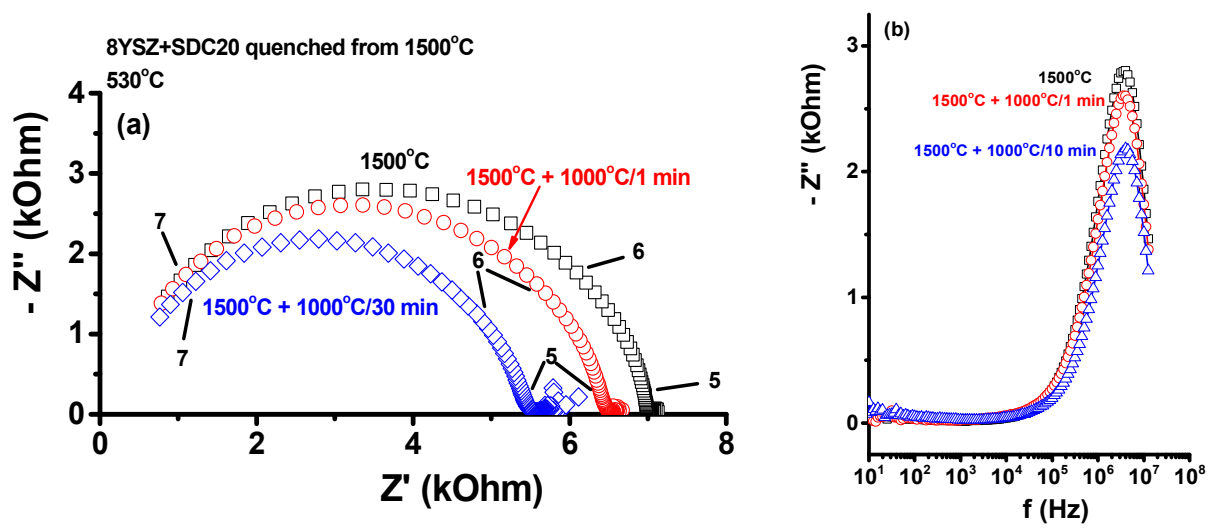

Figure 6. (a): impedance diagrams of ceramic pellets composed of equimolar mixture of $\mathrm{ZrO}_{2}: 8 \mathrm{~mol} \%$ $\mathrm{Y}_{2} \mathrm{O}_{3}+\mathrm{CeO}_{2}: 20 \mathrm{~mol} \% \mathrm{Sm}_{2} \mathrm{O}_{3}$, quenched from $1500{ }^{\circ} \mathrm{C}$ and annealed at $1000{ }^{\circ} \mathrm{C}$ for different times; numbers stand for $\log \mathrm{f}(\mathrm{f}: \mathrm{Hz})$. (b): corresponding Bode diagrams of the imaginary component of the impedance. Temperature of measurement: $530^{\circ} \mathrm{C}$.

Another experiment was required to assess what happens to a non-quenched similar sample. Instead of quenching, an equimolar mixture of $\mathrm{ZrO}_{2}: 8 \mathrm{~mol} \% \mathrm{Y}_{2} \mathrm{O}_{3}+\mathrm{CeO}_{2}: 20 \mathrm{~mol} \% \mathrm{Sm}_{2} \mathrm{O}_{3}$ was heated to $1500{ }^{\circ} \mathrm{C} / 2 \mathrm{~h}$ with $10{ }^{\circ} \mathrm{C} / \mathrm{min}$ heating and cooling rates. The impedance diagrams of this sample were measured at $310^{\circ} \mathrm{C}$ and $530{ }^{\circ} \mathrm{C}$, and are shown in Figure 7 . The total resistance measured at $310{ }^{\circ} \mathrm{C}\left(530{ }^{\circ} \mathrm{C}\right)$ is $74 \mathrm{kOhm}(3.47 \mathrm{kOhm})$ for the sintered sample and $170 \mathrm{kOhm}(19.7 \mathrm{kOhm})$ after further annealing at $1000{ }^{\circ} \mathrm{C} / 1 \mathrm{~min}$. As the increase of the electrical resistance could be due to destabilization of the tetragonal phase, $\mathrm{X}$-ray diffraction experiments were carried out at the specimen before and after the $1000{ }^{\circ} \mathrm{C}$ annealing. The $\mathrm{X}$-ray diffraction patterns of both specimens are shown in Figure 8 in the $72-95^{\circ} 2 \theta$ range. In this range, it is possible to distinguish unequivocally the reflections due to the cubic and the tetragonal phases (\#30-1468 and \#82-1245 JCPDS files).

(a) $8 \mathrm{YSZ}+\mathrm{SDC} 20,310^{\circ} \mathrm{C}$

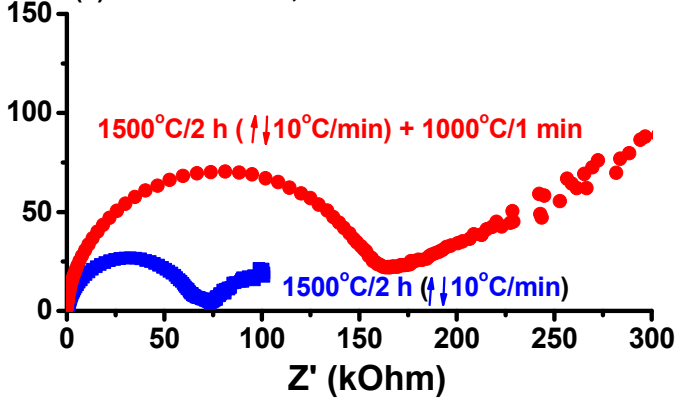

(b) $8 Y S Z+S D C 20,530^{\circ} \mathrm{C}$

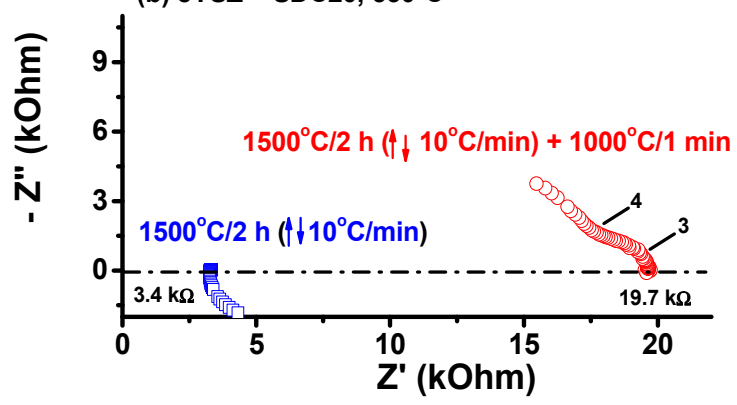

Figure 7. Impedance diagrams of equimolar $\mathrm{ZrO}_{2}: 8 \mathrm{~mol} \% \mathrm{Y}_{2} \mathrm{O}_{3}+\mathrm{CeO}_{2}: 20 \mathrm{~mol} \% \mathrm{Sm}_{2} \mathrm{O}_{3}$ sintered at $1500{ }^{\circ} \mathrm{C} / 2 \mathrm{~h}$ with $0.17^{\circ} \mathrm{C} / \mathrm{s}$ heating and cooling rates, and after further annealing at $1000{ }^{\circ} \mathrm{C} / 30 \mathrm{~min}$. Temperature of measurement: (a) $310^{\circ} \mathrm{C}$ and (b) $530{ }^{\circ} \mathrm{C}$. Numbers stand for $\log \mathrm{f}$ (f: Hz). 


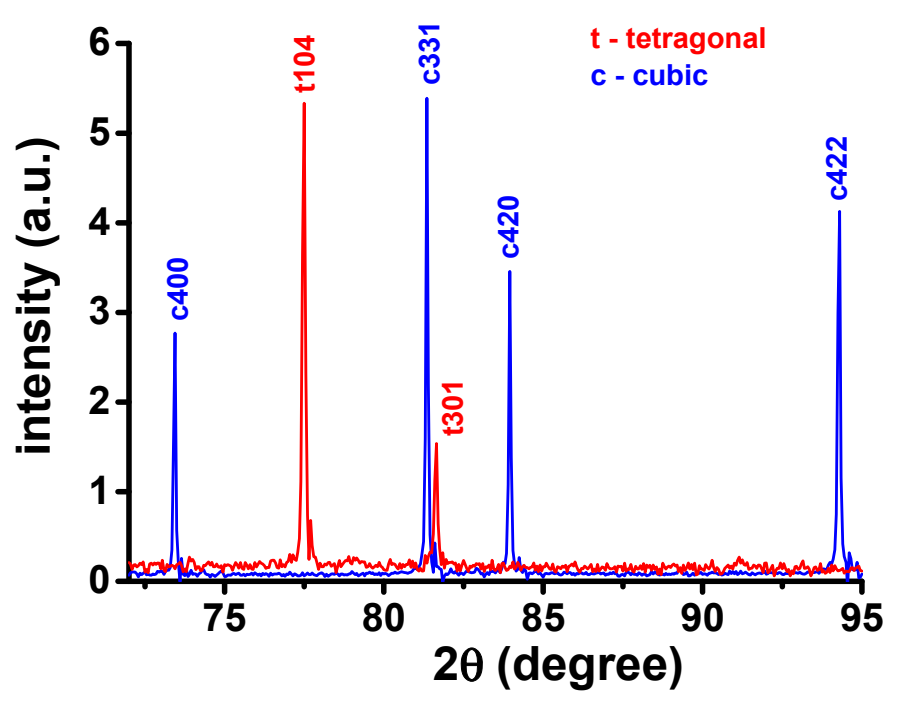

Figure 8. X-ray diffraction patterns of equimolar $\mathrm{ZrO}_{2}: 8 \mathrm{~mol} \% \mathrm{Y}_{2} \mathrm{O}_{3}+\mathrm{CeO}_{2}: 20 \mathrm{~mol} \% \mathrm{Sm}_{2} \mathrm{O}_{3}$ sintered at $1500{ }^{\circ} \mathrm{C} / 2 \mathrm{~h}$ with $0.17^{\circ} \mathrm{C} / \mathrm{s}$ heating and cooling rates (thkl), and after further annealing at $1000^{\circ} \mathrm{C} / 1 \mathrm{~min}(\mathrm{chkl})$; thkl and chkl stand for tetragonal and cubic phases with the Miller indices.

\section{Discussion}

\subsection{X-ray Diffraction Analysis}

Quenching from $1200,1300,1400$ and $1500{ }^{\circ} \mathrm{C}$, the compacts of the equimolar mixture of zirconia: $8 \mathrm{~mol} \%$ yttria and ceria: $20 \mathrm{~mol} \%$ samaria shows the evolution of the two original cubic fluorite structures to a new structure. Moreover, the $\mathrm{X}$-ray diffraction peaks are narrow, and no other peaks are detected. The Rietveld analysis, Figure 3, shows that this phase is a cerium zirconate tetragonal phase, and are in agreement with the reports on oxidized pyrochlore equimolar cerium zirconate [32,33]. The identification of the four first peaks, from the left, with Miller indices was performed according to \#152175 ICSD file [34]; the remaining peaks were tentatively ascribed to known peaks of stabilized tetragonal zirconias.

\subsection{Scanning Electron Microscopy}

The FEG-SEM images of 8YSZ and SDC20 quenched from $1500{ }^{\circ} \mathrm{C}$ are apparently almost fully densified, presenting large (micron size) and small (submicron size) grains, respectively. The equimolar sample of the quenched sample, on the other hand, has wide distribution of micron size irregular grains, the large grains being stressed due to local tension to accommodate the new tetragonal phase.

\subsection{Impedance Spectroscopy Analysis}

High electrical resistances have already been observed in single-phase high-entropy fluorite oxides in comparison with $8 \mathrm{YSZ}$ [8]. One may consider that at $1500{ }^{\circ} \mathrm{C}$ all impurities and dopants are diluted into the bulk of the samples, and quenching to room temperature may freeze that configuration; therefore, the blocking of oxide ions at the grain boundaries will decrease due to a reduced concentration of chemical species at the grain-to-grain interfaces. Chemical species are known to be accumulated or depleted at the interfaces, creating a space charge region, considered responsible for ion blocking, leading to the grain boundary resistivity detected in the impedance diagrams in conventionally sintered oxides [29]. This means that after quenching from $1500{ }^{\circ} \mathrm{C}$ there is not enough accumulated or depleted charged chemical species at the interfaces, i.e., there is a decrease of the chemical potential due to those charged species at the space charge region. The configuration of defects achieved upon quenching is a metastable thermodynamic state at room temperature. Heating to $530{ }^{\circ} \mathrm{C}$ to collect the impedance spectroscopy data is not sufficient to destabilize that state, and the 
sample has a limited space charge region, with little or no blocking of oxide ions at the grain boundaries; the opposite situation may happen in samples slowly cooled (not quenched) to room temperature. Two main reasons may be responsible for the increase in total electrical resistivity of the quenched sample, comparing to those of the individual components: association of defects like $\left(\mathrm{Y}_{\mathrm{Zr}^{\prime}}-\mathrm{V}_{\mathrm{O}}\right.$ •• $\left.-\mathrm{Y}_{\mathrm{Zr}^{\prime}}\right)$ and $\left(\mathrm{Sm}_{\mathrm{Ce}^{\prime}}-\mathrm{V}_{\mathrm{O}}{ }^{\bullet \bullet}-\mathrm{Sm}_{\mathrm{Ce}}{ }^{\prime}\right)$, provided the oxygen vacancy-dopant association remains after the high temperature treatment, and/or micro-cracks produced by micro-tension created by the different thermal expansion coefficients of 8YSZ $\left(9.80 \times 10^{-6} \mathrm{~K}^{-1}\right.$ [35]) and SDC20 $\left(12.6 \times 10^{-6} \mathrm{~K}^{-1}\right.$ [36]), previously observed in the FEG-SEM micrographs (Figure 4). Dissociation of those defects and relief of mechanical stresses could be accomplished by annealing at temperatures lower than $1500{ }^{\circ} \mathrm{C}$. The quenched equimolar samples were then heat treated at $1000{ }^{\circ} \mathrm{C}$ for $1 \mathrm{~min}$ and $30 \mathrm{~min}$, and slowly cooled down to room temperature. A decrease of the electrical resistivity is measured (Figure 6).

Impedance spectroscopy analyses were carried out on equimolar $\mathrm{ZrO}_{2}: 8 \mathrm{~mol} \% \mathrm{Y}_{2} \mathrm{O}_{3}+\mathrm{CeO}_{2}$ : $20 \mathrm{~mol} \% \mathrm{Sm}_{2} \mathrm{O}_{3}$ sintered at $1500{ }^{\circ} \mathrm{C} / 2 \mathrm{~h}$ with $0.17{ }^{\circ} \mathrm{C} / \mathrm{s}\left(10{ }^{\circ} \mathrm{C} / \mathrm{min}\right)$ heating and cooling rates to compare with the impedance spectroscopy measurements in quenched samples. The behavior is the opposite of that observed in the quenched sample: there is an increase of the total electrical resistance, due to partial destabilization of the tetragonal phase, as indicated in Figure 8 after measurements at $310^{\circ} \mathrm{C}$ and $530^{\circ} \mathrm{C}$.

\section{Conclusions}

Quenching from $1500^{\circ} \mathrm{C}$, a compact composed of an equimolar mixture of $8 \mathrm{~mol} \%$ yttria-stabilized zirconia and $20 \mathrm{~mol} \%$ samarium-doped ceria, both having fluorite cubic structure, yielding a new compound with tetragonal structure, according to a detailed Rietveld analysis of the X-ray diffraction data. Even though the new compound had oxide ion resistivity higher than the starting compounds, it showed no blocking of oxide ions at the grain boundaries, suggesting that quenching inhibited the accumulation or depletion of charged chemical species into the grain boundaries, avoiding the formation of a space charge region at the interfaces. Improvement of the total electrical conductivity was achieved by heating the quenched samples to $1000{ }^{\circ} \mathrm{C}$, which probably caused the relief of micro-tension produced during quenching. Similarly, non-quenched specimens, on the other hand, showed blocking of oxide ions at the grain boundaries and a decrease in the total electrical conductivity after heat treating at $1000{ }^{\circ} \mathrm{C}$, ascribed (and confirmed) to change in the structural phase.

Author Contributions: R.M., D.Z.d.F. and E.N.S.M. conceived, designed, performed the experiments and wrote the paper.

Funding: CNEN, CNPq (Procs. 470952/2013-0, 303483/2013-0 and 311803/2015-6), and FAPESP (CEPID-CDMF Proc. 2013/07296-2).

Acknowledgments: To CEM (Federal University of ABC) for the Topas software availability. One of the authors (R.M.) is grateful to Federal University of ABC for the Senior Visiting Researcher fellowship.

Conflicts of Interest: The authors declare no conflict of interest. The founding sponsors had no role in the design of the study; in the collection, analyses, or interpretation of data; in the writing of the manuscript, and in the decision to publish the results.

\section{References}

1. Ye, Y.F.; Wang, Q.; Lu, J.; Liu, C.T.; Yang, Y. Design of high entropy alloys: A single-parameter thermodynamic rule. Scr. Mater. 2015, 104, 53-55. [CrossRef]

2. Ye, Y.F.; Liu, C.T.; Yang, Y. A geometric model for intrinsic residual strain and phase stability in high entropy alloys. Acta Mater. 2015, 94, 152-161. [CrossRef]

3. Zhang, Y.; Zuo, T.T.; Tang, Z.; Gao, M.C.; Dahmen, K.A.; Liaw, P.K.; Lu, Z.P. Microstructures and properties of high-entropy alloys. Prog. Mater. Sci. 2014, 61, 1-93. [CrossRef]

4. Tsai, M.-H.; Yeh, J.-W. High-Entropy Alloys: A Critical Review. Mater. Res. Lett. 2014, 2, 107-123. [CrossRef]

5. Host, C.M.; Sachet, E.; Borman, T.; Moballegh, A.; Dickey, E.C.; Hou, D.; Jones, J.L.; Curtarolo, S.; Maria, J.-P. Entropy-stabilized oxides. Nat. Commun. 2015, 6, 8485. [CrossRef] 
6. Bérardan, D.; Franger, S.; Dragoe, D.; Meena, A.K.; Dragoe, N. Colossal dielectric constant in high entropy oxides. Phys. Status Solidi-RRL 2016, 10, 328-333. [CrossRef]

7. Bérardan, D.; Franger, S.; Meena, A.K.; Dragoe, N. Room temperature lithium superionic conductivity in high entropy oxides. J. Mater. Chem. A 2016, 4, 9536-9541. [CrossRef]

8. Gild, J.; Samiee, M.; Braun, J.L.; Harrington, T.; Vega, H.; Hopkins, P.E.; Vecchio, K.; Luo, J. High-entropy fluorite oxides. J. Eur. Ceram. Soc. 2018, 38, 3578-3584. [CrossRef]

9. Sarkar, A.; Djenadic, R.; Wang, D.; Hein, C.; Kautenburger, R.; Clemens, O.; Hahn, H. Rare earth and transition metal based entropy stabilised perovskite type oxides. J. Eur. Ceram. Soc. 2018, 38, 2318-2327. [CrossRef]

10. Djenadic, R.; Sarkar, A.; Clemens, O.; Loho, C.; Botros, M.; Chakravadhanula, V.S.K.; Kubel, C.; Bhattacharya, S.S.; Gandhif, A.S.; Hahn, H. Multicomponent equiatomic rare earth oxides. Mater. Res. Lett. 2017, 5, 102-109. [CrossRef]

11. Dabrowa, J.; Stygar, M.; Mikuła, A.; Knapik, A.; Mroczka, K.; Tejchman, W.; Danielewski, M.; Martin, M. Synthesis and microstructure of the $(\mathrm{Co}, \mathrm{Cr}, \mathrm{Fe}, \mathrm{Mn}, \mathrm{Ni})_{3} \mathrm{O}_{4}$ high entropy oxide characterized by spinel structure. Mater. Lett. 2018, 216, 32-36. [CrossRef]

12. Jiang, S.; Hu, T.; Gild, J.; Zhou, N.; Nie, J.; Qin, M.; Harrington, T.; Vecchio, K.; Luo, J. A new class of high-entropy perovskite oxides. Scr. Mater. 2018, 142, 116-120. [CrossRef]

13. Minh, N.Q. Ceramic fuel cells. J. Am. Ceram. Soc. 1993, 76, 563-588. [CrossRef]

14. Goodenough, J.B. Oxide-ion electrolytes. Annu. Rev. Mater. Res. 2003, 33, 91-128. [CrossRef]

15. Ormerod, R.M. Solid oxide fuel cells. Chem. Soc. Rev. 2003, 32, 17-28. [CrossRef] [PubMed]

16. Minh, N.Q. Solid oxide fuel cell technology-features and applications. Solid State Ion. 2004, 174, $271-277$. [CrossRef]

17. Holtappels, P.; Vogt, U.; Graule, T. Ceramic materials for advanced solid oxide fuel cells. Adv. Eng. Mater. 2005, 7, 292-302. [CrossRef]

18. Steele, B.C.H. Appraisal of $\mathrm{Ce}_{1-\mathrm{y}} \mathrm{Gd}_{\mathrm{y}} \mathrm{O}_{2-\mathrm{y} / 2}$ electrolytes for IT-SOFC operation at 500 degree C. Solid State Ion. 2000, 129, 95-110. [CrossRef]

19. Brandon, N.P.; Skinner, S.; Steele, B.C.H. Recent advances in materials for fuel cells. Annu. Rev. Mater. Res. 2003, 33, 183-213. [CrossRef]

20. Lee, K.T.; Yoon, H.S.; Wachsman, E.D. The evolution of low temperature solid oxide fuel cells. J. Mater. Res. 2012, 27, 2063-2078. [CrossRef]

21. Patakangas, J.; Ma, Y.; Jing, Y.F.; Lund, P. Review and analysis of characterization methods and ionic conductivities for low-temperature solid oxide fuel cells (LT-SOFC). J. Power Sources 2014, 263, 315-331. [CrossRef]

22. Maier, J. Space charge regions in solid two phase systems and their conduction contribution-II contact equilibrium at the Interface of two ionic conductors and the related conductivity effect. Ber. Bunsenges Phys. Chem. 1985, 89, 355-362. [CrossRef]

23. Maier, J. Ionic-conduction in space charge regions. Prog. Solid State Chem. 1995, 23, 171-263. [CrossRef]

24. Guo, X.; Maier, J. Grain boundary blocking effect in zirconia: A Schottky barrier analysis. J. Electrochem. Soc. 2001, 148, E121-E126. [CrossRef]

25. Guo, X.; Sigle, W.; Fleig, J.; Maier, J. Role of space charge in the grain boundary blocking effect in doped zirconia. Solid State Ion. 2002, 154, 555-561. [CrossRef]

26. Lubomirsky, I.; Fleig, J.; Maier, J. Modeling of space charge effects in nanocrystalline ceramics: the influence of geometry. J. Appl. Phys. 2002, 92, 6819-6827. [CrossRef]

27. Guo, X.; Waser, R. Electrical properties of the grain boundaries of oxygen ion conductors: acceptor-doped zirconia and ceria. Prog. Mater. Sci. 2006, 51, 151-210. [CrossRef]

28. Shirpour, M.; Rahmati, B.; Sigle, W.; van Aken, P.A.; Merkle, R.; Maier, J. Dopant segregation and space charge effects in proton-conducting $\mathrm{BaZrO}_{3}$ perovskites. J. Phys. Chem. C 2012, 116, 2453-2461. [CrossRef]

29. Gregori, G.; Merkle, R.; Maier, J. Ion conduction and redistribution at grain boundaries in oxide systems. Prog. Mater. Sci. 2017, 89, 252-305. [CrossRef]

30. Kleitz, M.; Kennedy, J.H. Resolution of multicomponent impedance diagrams. In Fast Ion Transport in Solids; Mundy, J.N., Shenoy, G.K., Vashishta, P., Eds.; Elsevier: North Holland, The Netherlands, 1979; pp. 185-188. ISBN 10: 0444003533. 
31. Fletcher, J.G.; West, A.R.; Irvine, J.T.S. The AC Impedance response of the physical interface between yttria-stabilized zirconia and $\mathrm{YBa}_{2} \mathrm{Cu}_{3} \mathrm{O}_{7-\mathrm{x}}$. J. Electrochem. Soc. 1995, 142, 2650-2654. [CrossRef]

32. Otobe, H.; Nakamura, A.; Yamashita, T.; Minato, K. Oxygen potential and defect structure of oxygen-excess pyrochlore $\mathrm{Ce}_{2} \mathrm{Zr}_{2} \mathrm{O}_{7+x}$. J. Phys. Chem. Solids 2005, 66, 329-334. [CrossRef]

33. Urban, S.; Dolcet, P.; Möller, M.; Chen, L.; Klar, P.J.; Djerdj, I.; Gross, S.; Smarsly, B.M.; Over, H. Synthesis and full characterization of the phase-pure pyrochlore $\mathrm{Ce}_{2} \mathrm{Cr}_{2} \mathrm{O}_{7}$ and the $\mathrm{K}_{-} \mathrm{Ce}_{2} \mathrm{Zr}_{2} \mathrm{O}_{8}$ phases. Appl. Cataly. B Environ. 2016, 197, 23-34. [CrossRef]

34. Lamas, D.G.; Fuentes, R.O.; Fábregas, I.O.; Fernández de Rapp, M.E.; Lascalea, G.E.; Casanova, J.R.; Walsoe de Reca, N.E.; Craievich, A.F. Synchrotron X-ray diffraction study of the tetragonal-cubic phase boundary of nanocrystalline $\mathrm{ZrO}_{2}-\mathrm{CeO}_{2}$ synthesized by a gel-combustion process. J. Appl. Crystallogr. 2005, 38, 867-873. [CrossRef]

35. Montross, C.S.; Yokokawa, H.; Dokiya, M. Thermal stresses in planar solid oxide fuel cells due to thermal expansion differences. Brit. Ceram. Trans. 2002, 101, 85-93. [CrossRef]

36. Zheng, Y.; Zhou, M.; Ge, L.; Li, S.; Chen, H.; Guo, L. Effect of Dy on the properties of Sm-doped ceria electrolyte for IT-SOFCs. J. Alloys Compd. 2011, 509, 1244-1248. [CrossRef]

(C) 2018 by the authors. Licensee MDPI, Basel, Switzerland. This article is an open access article distributed under the terms and conditions of the Creative Commons Attribution (CC BY) license (http:/ / creativecommons.org/licenses/by/4.0/). 